\title{
Molecular characterization of Plasmodium falciparum DNA-3-methyladenine glycosylase
}

\author{
Nattapon Pinthong ${ }^{1}$, Paviga Limudomporn ${ }^{2}$, Jitlada Vasuvat ${ }^{1}$, Poom Adisakwattana ${ }^{3}$, Pongruj Rattaprasert ${ }^{1}$ \\ and Porntip Chavalitshewinkoon-Petmitr ${ }^{1 *}$ (D)
}

\begin{abstract}
Background: The emergence of artemisinin-resistant malaria parasites highlights the need for novel drugs and their targets. Alkylation of purine bases can hinder DNA replication and if unresolved would eventually result in cell death. DNA-3-methyladenine glycosylase (MAG) is responsible for the repair of those alkylated bases. Plasmodium falciparum (Pf) MAG was characterized for its potential for development as an anti-malarial candidate.
\end{abstract}

Methods: Native PFMAG from crude extract of chloroquine- and pyrimethamine-resistant $P$. falciparum K1 strain was partially purified using three chromatographic procedures. From bio-informatics analysis, primers were designed for amplification, insertion into pBAD202/D-TOPO and heterologous expression in Escherichia coli of recombinant PfMAG. Functional and biochemical properties of the recombinant enzyme were characterized.

Results: PfMAG activity was most prominent in parasite schizont stages, with a specific activity of $147 \mathrm{U} / \mathrm{mg}$ (partially purified) protein. K1 PFMAG contained an insertion of AAT (coding for asparagine) compared to 3D7 strain and 16\% similarity to the human enzyme. Recombinant PfMAG $(74 \mathrm{kDa})$ was twice as large as the human enzyme, preferred double-stranded DNA substrate, and demonstrated glycosylase activity over a pH range of 4-9, optimal salt concentration of 100-200 mM NaCl but reduced activity at $250 \mathrm{mM} \mathrm{NaCl}$, no requirement for divalent cations, which were inhibitory in a dose-dependent manner.

Conclusion: PFMAG activity increased with parasite development being highest in the schizont stages. K1 PfMAG contained an indel AAT (asparagine) not present in 3D7 strain and the recombinant enzyme was twice as large as the human enzyme. Recombinant PFMAG had a wide range of optimal pH activity, and was inhibited at high (250 mM) $\mathrm{NaCl}$ concentration as well as by divalent cations. The properties of PfMAG provide basic data that should be of assistance in developing anti-malarials against this potential parasite target.

Keywords: Plasmodium falciparum, DNA-3-methyladenine glycosylase, DNA repair, Malaria

\section{Background}

Malaria is one of the major infectious diseases threatening two-thirds of the world's population, especially those living in tropical and sub-tropical regions, imposing both a disease and economic burden in these countries [1]. The World Health Organization (WHO) reported 228 million

\footnotetext{
*Correspondence: porntip.pet@mahidol.ac.th

1 Department of Protozoology, Faculty of Tropical Medicine, Mahidol University, Bangkok, Thailand

Full list of author information is available at the end of the article
}

new cases of malaria in 2018, with $97 \%$ of the infection in sub-Saharan Africa caused by Plasmodium falciparum and resulting in 405,000 deaths, mainly of children [2].

Plasmodium falciparum causes most severity in terms of clinical pathology and complication in treatment as it readily develops resistance to all existing anti-malarial agents, including most recently the artemisinins [3, 4], highlighting the urgent need for identification of new parasite targets and development of safe and effective novel drugs targeting them. Although a malaria vaccine has recently become available, it only provides partial

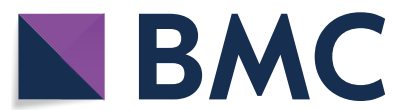

(c) The Author(s) 2020. This article is licensed under a Creative Commons Attribution 4.0 International License, which permits use, sharing, adaptation, distribution and reproduction in any medium or format, as long as you give appropriate credit to the original author(s) and the source, provide a link to the Creative Commons licence, and indicate if changes were made. The images or other third party material in this article are included in the article's Creative Commons licence, unless indicated otherwise in a credit line to the material. If material is not included in the article's Creative Commons licence and your intended use is not permitted by statutory regulation or exceeds the permitted use, you will need to obtain permission directly from the copyright holder. To view a copy of this licence, visit http://creativeco mmons.org/licenses/by/4.0/. The Creative Commons Public Domain Dedication waiver (http://creativecommons.org/publicdomain/ zero/1.0/) applies to the data made available in this article, unless otherwise stated in a credit line to the data. 
protection [5], and chemotherapeutic agents still play an essential role in malaria treatment and prevention.

Among the various parasite targets being studied for drug development, enzymes in $P$. falciparum DNA repair pathway present potential drugable targets, including $P$. falciparum uracil DNA glycosylase (PfUGD) [6], P. falciparum DNA polymerase delta (PfPol $\delta$ ) [7] and P. falciparum ATP-dependent DNA helicase RuvB3 (PfRuvB3) [8]. The parasite genome lacks genes encoding DNA repair enzymes in the non-homologous end joining pathway, but previous identification of PfPold [7] suggests parasite base excision repair mechanism might rely mainly on a long patch repair pathway [9].

The high $\mathrm{A}-\mathrm{T}$ content of the malaria parasite genome implies the potential of these regions being modified (alkylated), thereby the need of a parasite repair enzyme. DNA-3-methyladenine DNA glycosylase (MAG), a single sub-unit monofunctional DNA repair enzyme, belongs to an alkyladenine DNA glycosylase (AAG) superfamily, characterized by an antiparallel $\beta$-sheet and flanked by $\alpha$-helices [10]. The enzyme is capable of removing 3 -methyladenine $\left(\mathrm{m}^{3} \mathrm{~A}\right)$ as well as other cyclic adducts in DNA, such as $1, N^{6}$ ethenoadenine $(\varepsilon \mathrm{A}), 3, N^{4}$-ethenocytosine $(\varepsilon C), N^{2}, 3$-ethenoguaine $\left(N^{2}, 3-\varepsilon G\right)$, and $1, N^{2}$-ethenoguanine $\left(1, N^{2}-\varepsilon G\right)$ [11]. MAG orthologues are present in Escherichia coli, Saccharomyces cerevisiae, rodents, humans, and plants $[12,13]$. It is also known as $N$-methylpurine DNA glycosylase (MPG) due to its versatility in accommodating a variety of substrates in the active site [14]. MAG knockdown in animal models and cell cultures results in a modulation of sensitivity to alkylating agents $[15,16]$. In addition, 3-methyladenine and $1, N^{6}$-ethenoadenine are able to inhibit progression of DNA replication fork and thereby the DNA replication process [17-19]. In P. falciparum, after decades of debate [20$22]$ the existence of methylated cytosines $\left(\mathrm{me}^{5} \mathrm{C}\right)$ were finally identified in genomic DNA by the use of unbiased bisulfite conversion coupled with deep sequencing [23]. Recently, a hydroxymethylcytosine-like modification was identified at a higher extent compared with $\mathrm{me}^{5} \mathrm{C}$ and was linked to P. falciparum gene expression [24]. On the other hand, there is no available information to date with regards to purine methylation of the parasite. However, a gene encoding PfMAG was found located on chromosome 14 of chloroquine- and pyrimethamine-sensitive P. falciparum 3D7 strain comprising of 1506 nucleotides coding 501 amino acids (PlasmoDB: PF3D7_1467100).

Since MAG plays an important role in DNA repair and little is known regarding PfMAG, this provides an opportunity to study its properties as a potential target for antimalarial drug development [25]. Here, native PfMAG was partially purified from parasite crude extract to verify its expression in asexual parasites, and recombinant PfMAG was heterologously produced to allow further characterization of biochemical and functional properties.

\section{Methods \\ PfMAG activity determination of Plasmodium falciparum asexual stages}

Plasmodium falciparum K1 strain, a chloroquine- and pyrimethamine-resistant strain isolated in Thailand [26], was cultivated in RPMI 1640 medium (Invitrogen ${ }^{\mathrm{TM}}$, CA, USA) supplemented with $10 \%$ human serum and human red blood cells (RBCs) at $37^{\circ} \mathrm{C}$ using the candle jar method [27]. Media was changed daily and morphology and parasitaemia was observed under a light microscope $(1,000 \times$ magnification) using Giemsa-stained thin blood film. Parasite culture was initiated with $2 \%$ parasitaemia of ring forms obtained from sorbitol synchronization [28]. Ring, trophozoite and schizont stages were separately harvested when parasitaemia reached $20-30 \%$. Each parasite stage was prepared by incubating sedimented, infected RBCs with an equal volume of phosphate-buffered saline $\mathrm{pH} 7.6$ (PBS) containing $0.15 \%$ $(\mathrm{w} / \mathrm{v})$ saponin at $37{ }^{\circ} \mathrm{C}$ for $20 \mathrm{~min}$. Cell suspension was washed twice with PBS by centrifugation at $700 \times g$ at $25^{\circ} \mathrm{C}$ for $10 \mathrm{~min}$ and parasite pellet was stored at $-80^{\circ} \mathrm{C}$ until used.

Approximately $0.5 \mathrm{ml}$ aliquot of each stage of parasite pellet was resuspended in 4 volumes of extraction buffer (50 mM Tris- $\mathrm{HCl} \mathrm{pH} 7.6$ containing $1 \mathrm{mM}$ EDTA, $2 \mathrm{mM}$ DTT, $0.01 \%$ NP40 and $1 \mathrm{mM}$ PMSF) and cells were fragmented in a Dounce homogenizer. An equal volume of dilution buffer $(50 \mathrm{mM}$ Tris- $\mathrm{HCl} \mathrm{pH} 7.6$ containing $1 \mathrm{mM}$ EDTA, $2 \mathrm{mM}$ DTT, $20 \%$ (w/v) sucrose, $0.01 \% \mathrm{NP} 40$ and $1 \mathrm{mM}$ PMSF) was added to the sample and $3 \mathrm{M} \mathrm{KCl}$ was slowly added to the mixture to a final concentration of $0.5 \mathrm{M} \mathrm{KCl}$ while stirring on ice for $30 \mathrm{~min}$. Then the sample was centrifuged at $100,000 \times g$ at $4^{\circ} \mathrm{C}$ for $45 \mathrm{~min}$, supernatant dialysed at $4{ }^{\circ} \mathrm{C}$ overnight against buffer $\mathrm{A}$ (25 mM Tris- $\mathrm{HCl} \mathrm{pH} 8.5$ containing $1 \mathrm{mM}$ EDTA, $1 \mathrm{mM}$ PMSF, $1 \mathrm{mM} \mathrm{DTT,} \mathrm{5 \%} \mathrm{sucrose,} 20 \%$ glycerol, and $0.01 \%$ NP40) and used for assay of PfMAG activity.

\section{Partial purification of native PfMAG}

Parasite culture for partial purification of native PfMAG was carried out using a large-scale culture method [29]. Plasmodium falciparum cultures, containing mostly trophozoite and schizont stages, were harvested at $>20 \%$ parasitaemia by centrifugation at $500 \times g$ for $10 \mathrm{~min}$ at $25{ }^{\circ} \mathrm{C}$. Parasite pellet $(2 \mathrm{ml})$ was resuspended in extraction buffer, homogenized and parasite extract prepared as described above.

Parasite extract was loaded onto a HiTrap Q column (GE Healthcare, USA) equilibrated with buffer A and column then was washed with $10 \mathrm{ml}$ of buffer $\mathrm{A}$ and proteins 
were eluted using $10 \mathrm{ml}$ of a $0-1 \mathrm{M} \mathrm{KCl}$ linear gradient in buffer A. Fractions of $250 \mu \mathrm{l}$ were collected and $5 \mathrm{ml}$ aliquot of each fraction was tested for glycosylase activity. Fractions containing PfMAG activity were pooled and dialyzed against buffer $\mathrm{B}(50 \mathrm{mM}$ Tris $\mathrm{pH} 8.0$ containing $1 \mathrm{mM}$ PMSF, $2 \mathrm{mM}$ DTT, $1 \mathrm{mM}$ EDTA, 5\% sucrose, $20 \%$ glycerol, and $0.01 \%$ NP40) overnight at $4{ }^{\circ} \mathrm{C}$ and then loaded onto HiTrap Capto S column (GE Healthcare) equilibrated with buffer $B$. The column was washed with buffer $B$ and proteins were eluted with $15 \mathrm{ml}$ of a $0-1 \mathrm{M}$ $\mathrm{KCl}$ linear gradient in buffer B. Fractions of $250 \mu \mathrm{l}$ were collected, assayed for PfMAG activity and pooled fractions dialyzed against buffer $B$, then loaded onto Hitrap Heparin column (GE Healthcare) equilibrated with buffer B. Column was washed with buffer B and proteins eluted with $10 \mathrm{ml}$ of a $0-1 \mathrm{M} \mathrm{KCl}$ linear gradient in buffer $\mathrm{B}$. Fractions containing PfMAG activity were pooled and termed native PfMAG.

\section{PfMAG glycosylase assay}

Fluorescent-labelled 27-mer oligonucleotide 5'-[6FAM] CGATTAGCATCC TXCCT TCG TCG TCTCCAT-3' (where $\mathrm{X}=\varepsilon \mathrm{A}$ ) (Gene Link $^{\mathrm{TM}}$; NY, USA) was annealed to its complementary strand 5'-ATGGAGACGACGAAG GTAGGATGCTAATCG- $3^{\prime}$ at 1:2 molar ratios in 100 $\mu \mathrm{l}$ reaction containing TE buffer $(10 \mathrm{mM}$ Tris $-\mathrm{HCl} \mathrm{pH}$ 8 containing $1 \mathrm{mM}$ EDTA,). The annealing process was carried out by heating at $95{ }^{\circ} \mathrm{C}$ for $5 \mathrm{~min}$ and cooling to ambient temperature over a period of $30 \mathrm{~min}$, then the annealed substrate was stored at $4{ }^{\circ} \mathrm{C}$ until used.

PfMAG activity assay mixture $(25 \mu \mathrm{l})$ containing $50 \mathrm{mM}$ sodium phosphate $\mathrm{pH}$ 7, $1 \mathrm{mM}$ EDTA, $1 \mathrm{mM}$ DTT, $100 \mathrm{mM} \mathrm{NaCl}, 200 \mu \mathrm{g} / \mathrm{ml} \mathrm{BSA}, 0.5 \mu \mathrm{M}$ oligoduplex substrate and $1.5 \mathrm{mM}$ of recombinant PfMAG was incubated at $37{ }^{\circ} \mathrm{C}$ for $30 \mathrm{~min}$, then reaction terminated by $200 \mathrm{mM} \mathrm{NaOH}$ and heating at $95^{\circ} \mathrm{C}$ for $5 \mathrm{~min}$. The solution was mixed with an equal volume of loading buffer (98\% formamide, 10 mM EDTA and xylene cyanol FF and bromophenol blue dyes) and resolved on 16\% urea PAGE. The 27-mer and 13-mer products were visualized by VersaDoc 4000 MP (Biorad, USA) and quantified using an image-analysis software (Image Lab; Biorad, USA). Recombinant PfMAG activity was evaluated for substrate preference and optimal incubation time, $\mathrm{pH}$, and salt and divalent cations concentrations. One U MAG activity is defined as the amount of P $\mathrm{MAG}$ required to release $1 \mathrm{pmol}$ of $1, N^{6}$ ethenoadenine in $1 \mathrm{~min}$ at $37^{\circ} \mathrm{C}$.

In addition to double-stranded DNA as substrate, fluorescent-labelled, single-stranded 27-mer oligonucleotide was tested as DNA substrate of recombinant PfMAG compared to human DNA-3-methyladenine glycosylase (hAAG) (specificity of $5000 \mathrm{U} / \mathrm{mg}$; SigmaAldrich, Germany). Enzyme incubation time varied from
10 to $90 \mathrm{~min}$. Reactions were carried out as described above. PfMAG activity was tested in presence of $50 \mathrm{mM}$ citrate-sodium citrate buffer $\mathrm{pH} 3-5$, phosphate-citrate buffer $\mathrm{pH} 6-7$ and Tris- $\mathrm{HCl} \mathrm{pH}$ 8-9. PfMAG activity was determined in $50-500 \mathrm{mM} \mathrm{NaCl}$ under standard assay reaction described above, as well in the presence of $\mathrm{Fe}^{2+}, \mathrm{Mg}^{2+}$ and $\mathrm{Zn}^{2+}(0-3 \mathrm{mM})$ in the absence of EDTA. Relative activity of PfMAG was determined as amount of product divided by total amounts of substrate and product.

\section{Expression analysis of PfMAG using SYBR Green quantitative (q)PCR}

Total RNA was isolated from ring, growing trophozoite and schizont stages of P. falciparum using an Easy$\operatorname{Spin}^{\mathrm{TM}}$ (DNA-free) and total RNA extraction kit (iNtRON Biotechnology, South Korea). Purity of RNA in eluted samples $(50 \mu \mathrm{l})$ of was assessed using a NanoDrop ${ }^{\mathrm{TM}}$ spectrophotometer (Thermo Scientific, USA). Reverse transcription was carried out using a Maxime ${ }^{\mathrm{TM}}$ RT PreMix (Oligo (dT)15 Primer) kit (iNtRON Biotechnology, South Korea) in a reaction volume of $20 \mu \mathrm{l}$ at $45{ }^{\circ} \mathrm{C}$ for 60 min. PCR primers were designed based on alignment of a $P$. falciparum fragment (NCBI Accession No. XM_001348777) (Table 1), with serine-tRNA ligase as an internal control gene [30]. All amplifications were performed using a LightCycler ${ }^{\circledR}$ FastStart DNA Master SYBR Green I (Roche Applied Science, Germany). The following thermocycling conditions were used: $10 \mathrm{~min}$ at $95{ }^{\circ} \mathrm{C}$ for initial denaturation and enzyme activation; 45 cycles of $95{ }^{\circ} \mathrm{C}$ for $10 \mathrm{~s}, 55^{\circ} \mathrm{C}$ for $5 \mathrm{~s}$ and $72{ }^{\circ} \mathrm{C}$ for $10 \mathrm{~s}$; followed by melting curve analysis of $65-95{ }^{\circ} \mathrm{C}$. Melting temperature of PfMAG and serine-tRNA ligase cDNA was 72.9 and $74.5^{\circ} \mathrm{C}$, respectively. Relative quantification of PfMAG expression employed a $2^{-\Delta \Delta \mathrm{Ct}}$ method [31]. Three independent experiments were performed in duplicate for each parasite sample.

\section{PCR amplification of PfMAG}

DNA of $P$. falciparum strain K1 was extracted using QIAamp DNA Blood Mini Kit (Qiagen, USA). PfMAG was amplified using forward primer 5'-CACCATGGAA

\begin{tabular}{|c|c|c|}
\hline Primer name & Sequence & Reference \\
\hline PfMAGexpressF & GGAACCAACAAGGGAACATATCA & In house \\
\hline PfMAGexpressR & TTGTTACACATCCAGGACCACT & In house \\
\hline s-tRNA syn F & AAGTAGCAGGTCATCGTGGTT & {$[30]$} \\
\hline$s-t R N A$ syn $R$ & TTCGGCACATTCTTCCATAA & [30] \\
\hline
\end{tabular}


AAAATGAACGAATTC-3' designed from the start codon and incorporating a specific sequence at $5^{\prime}$ end (CACC) for unidirectional cloning and reverse primer 5'-TTTGGG AAAAATAGATACGGATGG-3' designed for full-length gene amplification; primers design used $P$. falciparum strain 3D7 as template (NCBI accession no. XM_001348777). Amplification was performed (using Phusion $^{\mathrm{TM}}$ High-Fidelity PCR Kit; Finzyme OY, Finland) as follows: $98{ }^{\circ} \mathrm{C}$ for $5 \mathrm{~min}$; 35 cycles of $98{ }^{\circ} \mathrm{C}$ for $30 \mathrm{~s}$, $55{ }^{\circ} \mathrm{C}$ for $30 \mathrm{~s}$ and $72{ }^{\circ} \mathrm{C}$ for $30 \mathrm{~s}$; with a final heating at $72{ }^{\circ} \mathrm{C}$ for 3 min.

\section{Cloning, heterologous expression and purification of recombinant $P f M A G$}

Amplified full-length PfMAG was ligated into expression vector $\mathrm{pBAD} 202 / \mathrm{D}-\mathrm{TOPO}$ (Invitrogen, USA). The constructed recombinant plasmid was verified by DNA sequencing and compared to its known $P$. falciparum 3D7 counterpart. Escherichia coli LMG 194 harbouring recombinant $\mathrm{pBAD}-\mathrm{PfMAG}$ was grown in $\mathrm{LB}$ media containing $50 \mu \mathrm{g} / \mathrm{ml}$ kanamycin sulfate at $37{ }^{\circ} \mathrm{C}$, with shaking at $200 \mathrm{rpm}$ for $2 \mathrm{~h}$. When $\mathrm{A}_{600 \mathrm{~nm}}$ of the culture reached 0.4, incubation temperature was reduced to $15{ }^{\circ} \mathrm{C}$ and shaking was continued for a further $1 \mathrm{~h}$. L-arabinose $(0.02 \% \mathrm{w} / \mathrm{v})$ was then added to induce recombinant protein expression and the culture was shaken for $16 \mathrm{~h}$. Following sedimentation, bacterial pellet was suspended in lysis buffer $\left(50 \mathrm{mM} \mathrm{NaH} \mathrm{PO}_{4} \mathrm{pH} 8.0\right.$ containing $300 \mathrm{mM} \mathrm{NaCl}$ and $10 \mathrm{mM}$ imidazole) and lysed by sonication on ice for $10 \mathrm{~min}$. Then the sample was centrifuged at $10,000 \times g$ at $4{ }^{\circ} \mathrm{C}$ for $30 \mathrm{~min}$, supernatant added to an equal volume of lysis buffer and loaded onto a HisTrap HP column (GE Healthcare) pre-equilibrated with lysis buffer. The column was washed with washing buffer $\left(50 \mathrm{mM} \mathrm{NaH} \mathrm{PO}_{4} \mathrm{pH} 8.0\right.$ containing $300 \mathrm{mM} \mathrm{NaCl}$ and $50 \mathrm{mM}$ imidazole) and protein eluted with a linear $10-500 \mathrm{mM}$ imidazole gradient. Fractions $(250 \mu \mathrm{l})$ with enzyme activity were pooled and subjected to $12 \%$ SDSPAGE, staining with Coomassie blue R250 and western blotting. The latter employed mouse anti-His primary antibody (Invitrogen, USA) (1:3000 dilution) and rabbit HRP-conjugated anti-mouse IgG antibody (1:5000 dilution). Immunoreactive protein band was visualized by treatment with a mixture of hydrogen peroxide and 3,3'-diaminobenzidine tetrahydrochloride (DAB).

\section{D structure prediction of PfMAG}

In view of a lack of $3 \mathrm{D}$ structural models of PfMAG, a predicted structure was constructed using the 502-amino acid sequence of PfMAG $\mathrm{K} 1$ as input for simulation of PfMAG by a protein threading method using I-TASSER server [32-34] and a Pymol software to align PfMAG and superimpose on human AAG structure.

\section{Results}

\section{Partial purification of native PfMAG}

Native PfMAG activity was monitored according to $P$. falciparum developmental stages. Relative to hAAG, native PfMAG activity was $3.1,10.8$ and $12.3 \%$ in ring, trophozoite and schizont stage, respectively. Crude extract of $P$. falciparum trophozoite and schizont stages from synchronized culture were subjected to purification of PfMAG employing sequential anion exchange, cation exchange and heparin affinity chromatography. The results of the partial purification of PfMAG are summarized in Table 2 and its purification profile was demonstrated in Fig. 1. Ultimately a partially purified enzyme was eluted Hitrap Heparin affinity column employing a linear $0.3-0.6 \mathrm{M} \mathrm{KCl}$ gradient (Fig. 1). Two milliliter of parasite pellet yielded $140 \mu \mathrm{g}$ of 38 -fold purified PfMAG, specific activity of $147 \mathrm{U} / \mathrm{mg}$ protein. These results indicated existence of a functionally active PfMAG that increased with parasite development.

\section{Expression of PfMAG during asexual stage development}

SYBR Green qPCR indicated PfMAG mean expression level of trophozoite and schizont stage was 0.5 and 3.2-fold(s) of ring form, respectively (Fig. 2), in keeping with relative enzyme activity being highest in schizonts. It was of interest to note the lack of significant difference in PfMAG expression level between ring and trophozoite.

\section{Analysis of PfMAG nucleotide sequence}

The 1506-bp amplicon of K1 PfMAG (Fig. 3a) showed 99\% identity with that of P. falciparum chloroquinesensitive strain 3D7 strain (NCBI reference sequence

Table 2 Partial purification of native MAG from crude extract of Plasmodium falciparum K1 strain

\begin{tabular}{llcccc}
\hline Fraction & Total activity (U) & Total protein (mg) & $\begin{array}{l}\text { Specific activity (U/ } \\
\text { mg) }\end{array}$ & Yield (\%) & $\begin{array}{l}\text { Purification } \\
\text { fold }\end{array}$ \\
\hline Crude extract & 41.6 & 10.6 & 3.9 & 100 & - \\
HiTrap Capto Q (unbound) & 25.4 & 3.7 & 6.8 & 61.0 & 1.7 \\
HiTrap Capto S & 26.0 & 0.3 & 96.2 & 62.4 & 24.6 \\
HiTrap Heparin & 20.6 & 0.1 & 147.4 & 49.6 & 37.7 \\
\hline
\end{tabular}



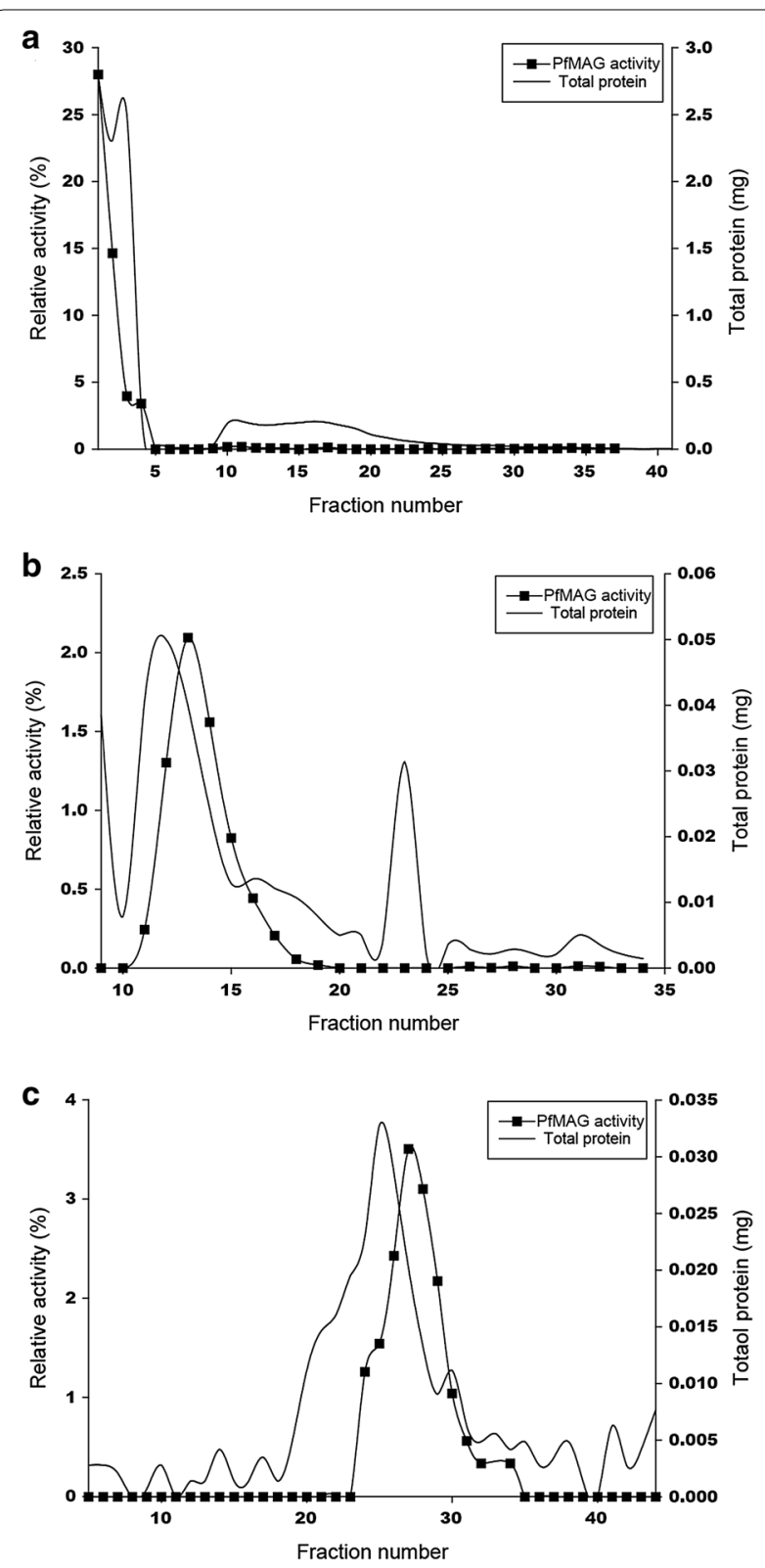

Fig. 1 Partial purification of native PFMAG. Purification of parasite crude extract using HiTrap Capto Q column where unbound fractions were collected (a). Active fractions from HiTrap Capto Q column were purified using HiTrap Capto S column (b). Pooled active fractions from HiTrap Capto S column were purified using HiTrap Heparin HP column (c)

XP_001348813.1) due to the presence of 3-nucleotide (AAT) sequence between nt 25 and 29 (Additional file 1: Figure S1), corresponding to an insertion of asparagine $(\mathrm{N})$ at position 9 of the 502-amino acid recombinant enzyme (Additional file 1: Figure S2) but the insertion is not at the active site (Additional file 1: Figure S3), which is conserved among many organisms, including
Plasmodium spp. The predicted molecular mass of PfMAG is $59.3 \mathrm{kDa}$ with a pI of 9.07 . There is only $16 \%$ amino acid sequence similarity of PfMAG compared to that of human enzyme. In addition, the predicted amino acid sequence of K1 PfMAG was much different from those of MAGs in other organisms including Plasmodium spp. ( 40\%) (Table 3$)$.

\section{Simulated 3D structure of PfMAG}

In view of a lack of an X-ray crystal structure of PfMAG, a simulated 3D structure was constructed based on alignment with that of hAAG (PDB 1F6O) at $41 \%$ coverage with RMSD of $2.13 \AA$ (Fig. 4). PfMAG (putatively) contained $20 \alpha$-helixes, $11 \beta$-sheets and 31 loops compared to its human orthologue with $14 \alpha$-helixes, $8 \beta$-sheets and 22 loops. As expected, the additional $\mathrm{N}$ residue is located in a coil region not involved in substrate binding.

\section{Characterization of recombinant PfMAG}

The affinity-purified recombinant PfMAG had a molecular mass of $74 \mathrm{kDa}$ (Fig. 3b). Western blotting revealed several faint immunoreactive bands of truncated/ degraded proteins $(\sim 55-\mathrm{kDa})$ accounting for about $15 \%$ of total purified protein (Fig. 3c). Specific activity of the affinity-purified recombinant PfMAG was $1309 \mathrm{U} / \mathrm{mg}$. Recombinant PfMAG acted on double-stranded DNA substrate similar to hAAG control (Fig. 5) and converted a 27-mer double-stranded DNA substrate containing $\varepsilon$ A into a 13 -mer product (90\% yield) after for $30 \mathrm{~min}$. PfMAG activity on single-stranded substrate was not as clearly demonstrated as with hAAG.

Recombinant PfMAG had activity over a wide $\mathrm{pH}$ range (4-9) (Fig. 6a) but activity was significantly reduced at $\mathrm{pH} 3$, with optimal activity between $\mathrm{pH} 6$ and 7 in a phosphate-citrate buffer. The enzyme had $45.5 \%$ relative activity at low-salt concentrations $(0-50 \mathrm{mM})$ and $38.9 \%$ at $500 \mathrm{mM}$ compared to optimal concentration of 100 $200 \mathrm{mM} \mathrm{NaCl}$ that generated $86.3 \%$ of product (Fig. $6 \mathrm{~b}$ ). There was no requirement of any divalent cations $\left(\mathrm{Fe}^{2+}\right.$, $\mathrm{Mg}^{2+}$ or $\mathrm{Zn}^{2}$ ) for PfMAG activity (Fig. $6 \mathrm{c}$ ); $\mathrm{MgCl}_{2}$ did not affect glycosylase activity up to $3 \mathrm{mM}$, but iron and zinc sulfate inhibited enzyme activity at $500 \mu \mathrm{M}$.

\section{Discussion}

Cellular DNA is constantly damaged by a variety of endogenous metabolites [35]. MAG, a DNA repair enzyme, has multiple substrate specificities, such as methylpurines, ethenopurines and hypoxanthine [3638]. The enzyme can initiate both short- and long-patch base excision in an alkylated base repair process [39] by intercalating a tyrosine residue between two bases in the DNA strand with subsequent hydrolysis of the $\mathrm{N}$-glycosylic bond [40]. Owing to the $80 \%$ A-T content of $P$. 

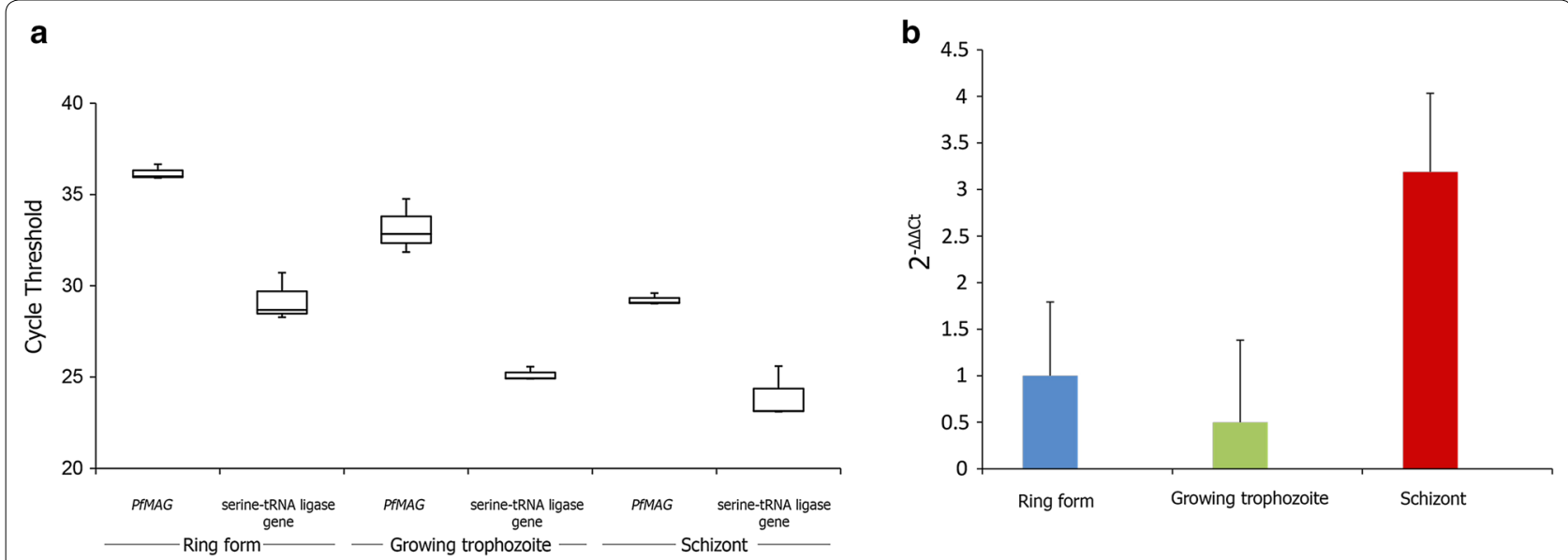

Fig. 2 Expression of PFMAG during asexual stage development. a PCR cycle threshold $\left(C_{t}\right)$ values of expression levels of PfMAG and serine-tRNA ligase gene are shown as mean (horizontal line), 25th to 75th percentile (box) and range (vertical) for ring, trophozoite and schizont samples. b Fold change in PfMAG expression of ring, trophozoite and schizont are shown with their standard deviations
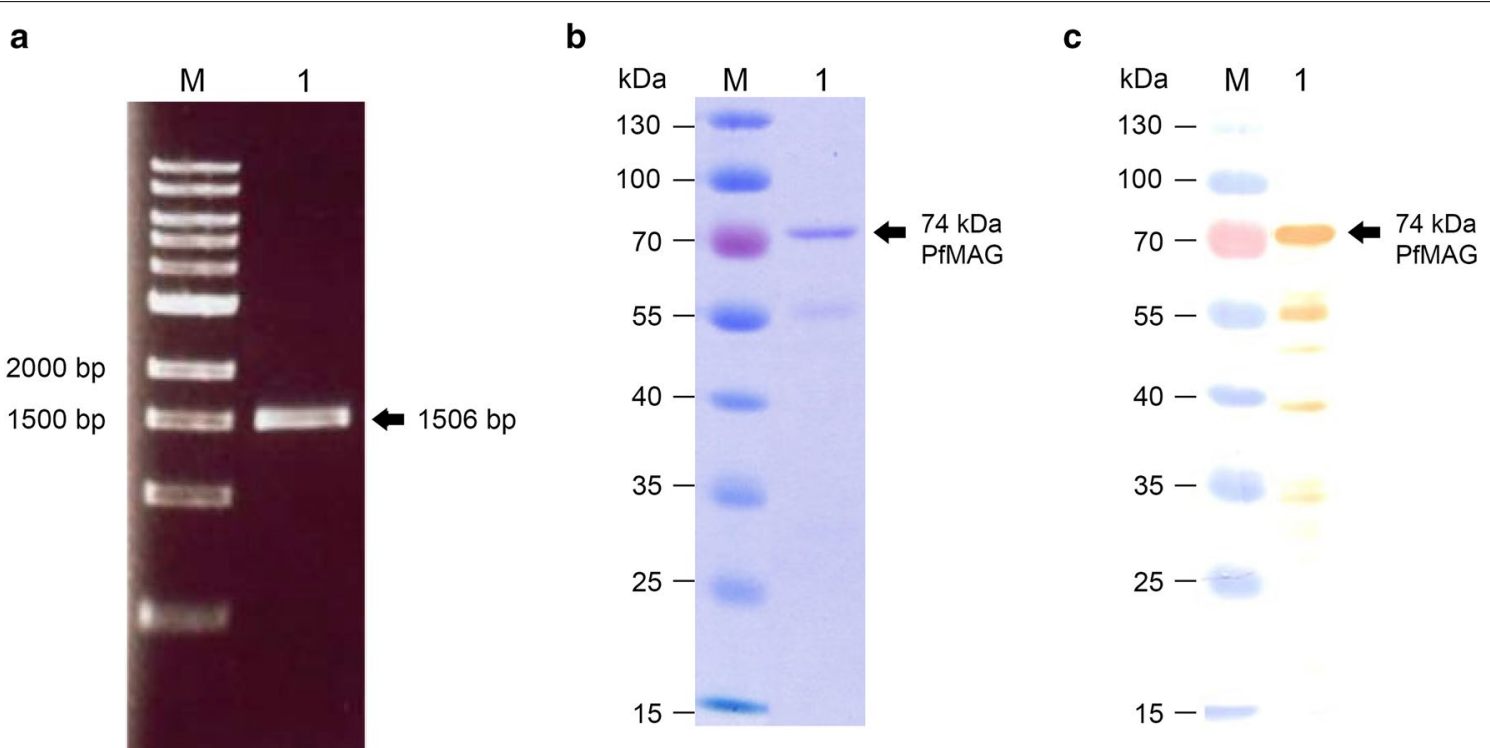

Fig. 3 Amplification of PFMAG and expression of recombinant PfMAG. a PCR amplification of P. falciparum DNA-3-methyladenine glycosylase gene. Lane M, DNA size ladder; lane 1, PfMAG amplicon. b SDS-PAGE and $\mathbf{c}$ western blotting of recombinant PfMAG heterologously expressed in E. coli LMG 194 at $15^{\circ} \mathrm{C}$ for $16 \mathrm{~h}$. Recombinant protein was purified using HisTrap HP column and eluted with a 10-500 mM imidazole linear gradient. Lane M, standard protein size markers; lane 1, purified PfMAG eluted at $500 \mathrm{mM}$ imidazole

falciparum whole genome, high numbers of unrepaired alkylated adenine bases constitute a threat to parasite growth and development.

Highest $P f$ MAG activity was found in schizont stages, which correlated with gene expression, but this association was not observed between ring and trophozoite stages. There are reports indicating a large proportion of parasite transcriptional activity, measured during intraerythrocytic development cycle, does not correlate with protein abundance [41, 42], as observed in mammalian cells where, often time, initiation of translation and not transcript abundance is the main determinant of protein levels [43]. In Arabidopsis thaliana, expression of DNA3-methyladenine glycosylase is also rapidly elevated in dividing tissues and correlates with DNA replication [44]. The human $\mathrm{N}$-methylpurine DNA glycosylase (MPG) orthologue is overexpressed in several types of cancers [45]. 
Table 3 Amino acid sequence similarity of MAG from Plasmodium falciparum K1 strain compared to MAGs from other organisms

\begin{tabular}{lll}
\hline Organism & Similarity (\%) & $\begin{array}{l}\text { NCBI protein reference } \\
\text { sequence accession } \\
\text { number }\end{array}$ \\
\hline P. falciparum 3D7 & 99 & XP_001348813.1 \\
P. berghei & 45 & XP_679046.1 \\
P. chabaudi & 44 & XP_740495.2 \\
P. knowlesi & 41 & XP_002260194.1 \\
P. vivax & 40 & EDL45990.1 \\
Mus musculus & 18 & NP_034952.2 \\
Arabidopsis thaliana & 17 & NP_187811.1 \\
Homo sapiens & 16 & XP_024306050.1 \\
Helicobacter pylori & 15 & EMJ39070.1 \\
Escherichia coli & 7 & WP_020233157.1 \\
Saccharomyces cerevisiae & 6 & P22134.1 \\
\hline
\end{tabular}

Low yield from purification of native PfMAG precluded any further characterization of the parasite enzyme other than determination of molecular mass and purity. As in many other studies of malaria parasite enzymes, heterologous expression and affinity purification of recombinant proteins is the recourse in lieu of labour-intensive, largescale parasite cultivation. The presence of small protein fragments from Escherichia coli-expression suggests use of a eukaryote expression host might improve yield and quality of the recombinant protein.

Surprisingly, K1 PfMAG contains an extra asparagine residue at codon 9 compared to 3D7 PfMAG, but based on sequence location and that from a simulated $3 \mathrm{D}$ structure, this indel mutation does not appear to affect enzyme activity. Interestingly, PfMAG is nearly twofold larger than of hAAG [46]. The simulated 3D structure of the parasite enzyme shows the extended region consisting of $8 \alpha$-helices, $3 \beta$-sheets and 11 loops located at the $\mathrm{C}$-terminus of the parasite protein, and this additional sequence does not bear homology with any other orthologues.

Unlike hAAG, PfMAG was less capable of acting on single-stranded DNA substrate. HAAG is able to excise $\varepsilon A$ from single-stranded DNA albeit at low efficiency [38], suggesting the possible role of other parasite glycosylase(s) in the repair of these frequent lesions in single-stranded DNA transiently generated during replication and transcription. For instance, in Escherichia coli, 3-methyladenine glycosylase has been shown to remove 3-methyladenine from single-stranded DNA [47], and bovine uracil DNA glycosylase [48] and human singlestrand selective monofunctional uracil DNA glycosylase [49] also excises uracil from single-stranded DNA substrate.
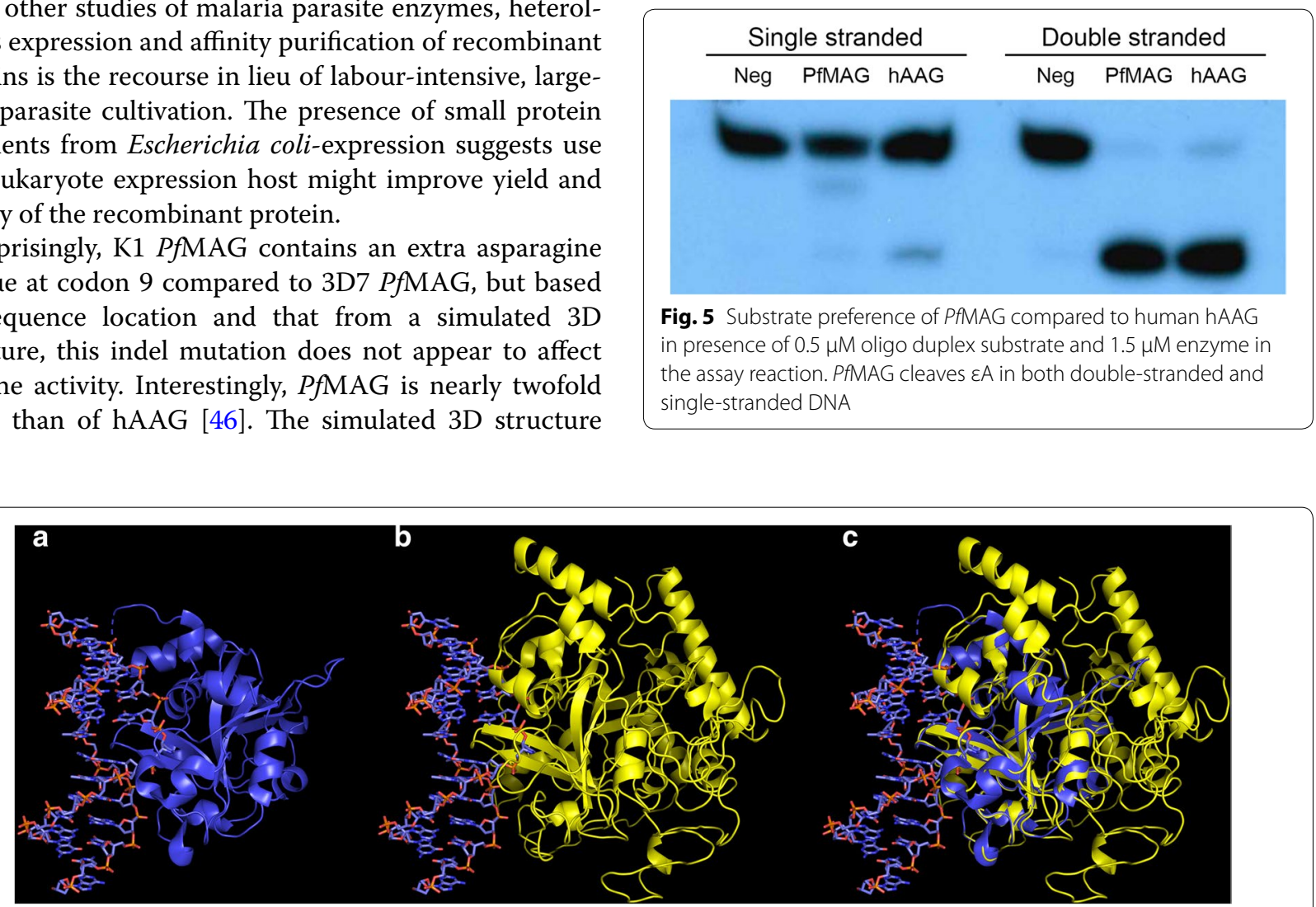

Fig. 4 Structural comparison of PfMAG with hAAG. a Binding of hAAG (219 residues) with double-strand DNA containing pyrrolidine (PDB 1f6O). Tyr162 intercalates into DNA duplex, flipping pyrrolidine into the active site. b Simulated 3D structure of PfMAG (502 residues) using I-TASSER server. Tyr171 intercalates into DNA strand flipping pyrrolidine into the active site. c PFMAG structure is superimposed on that of hAAG showing similarity of catalytic domain of both proteins and the extended C-terminus of the parasite protein 


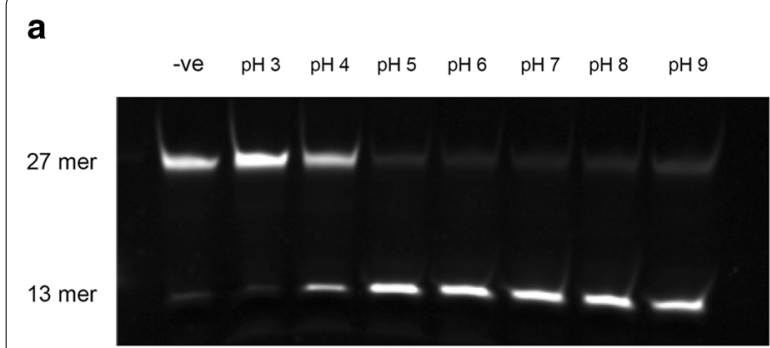

b $\begin{array}{lllllllllllll}\text {-ve } & 0 & 50 & 100 & 150 & 200 & 250 & 300 & 350 & 400 & 450 & 500 & \mathrm{mM}\end{array}$
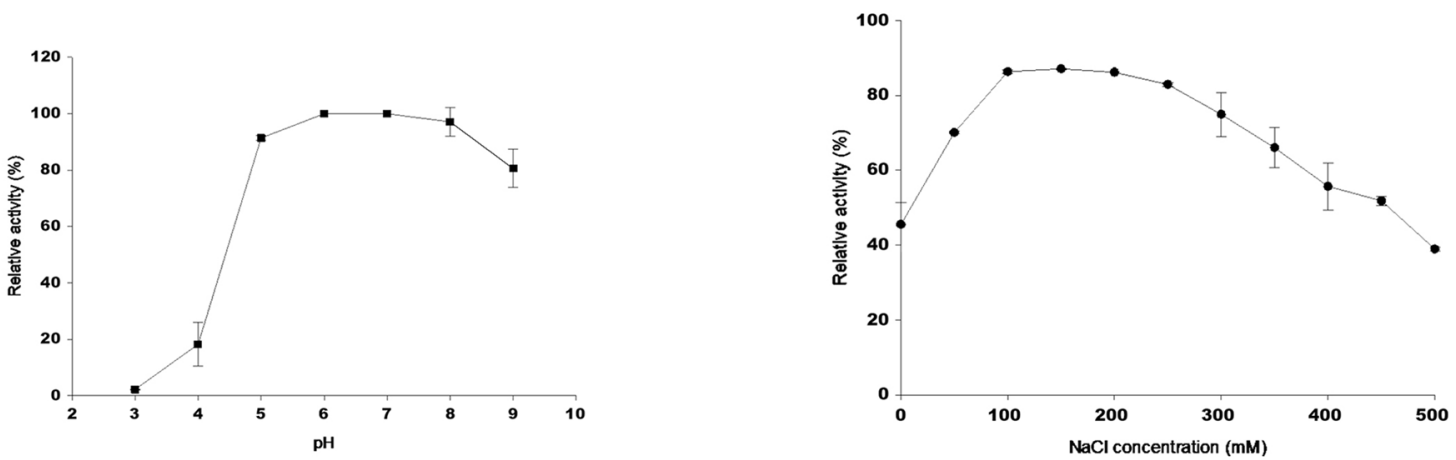

C

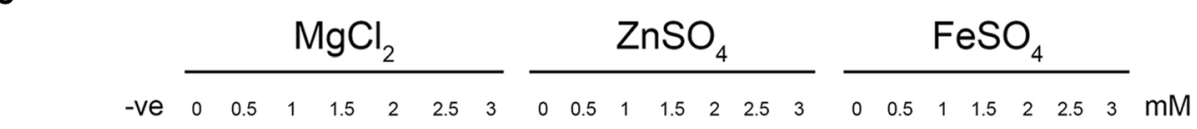

27 mer

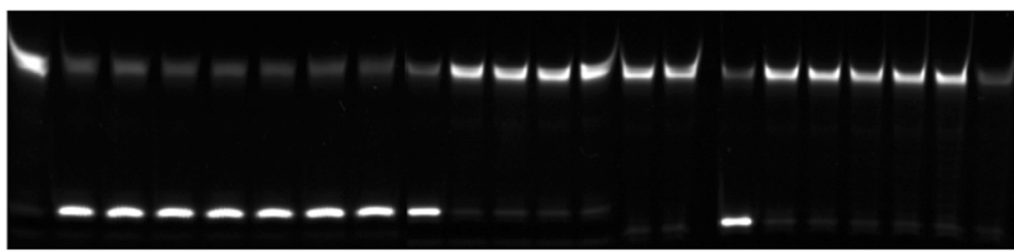

13 mer

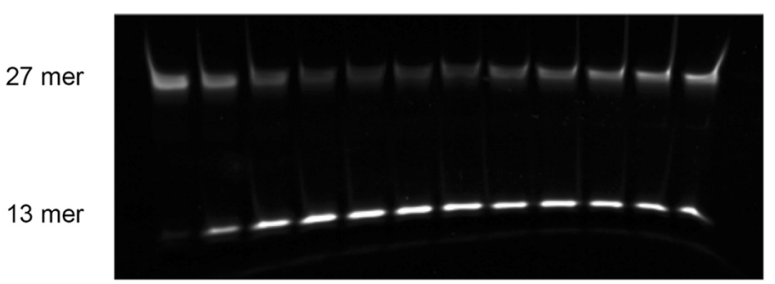

(3)

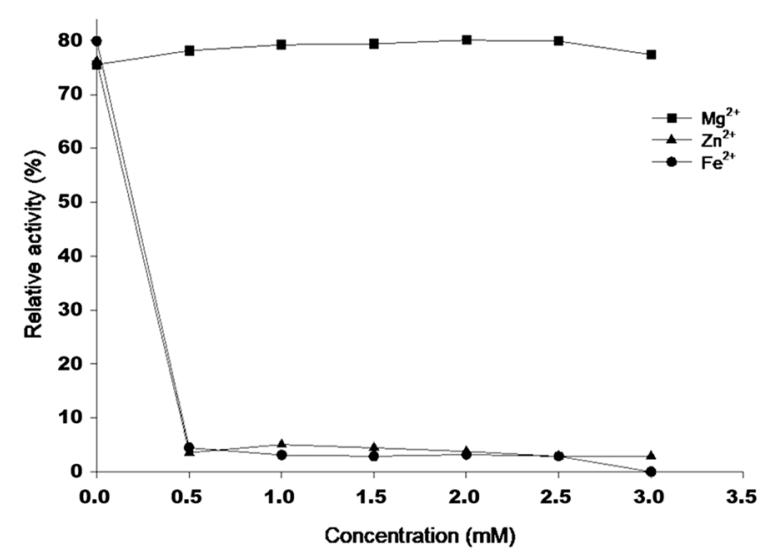

Fig. 6 Effects of different buffer conditions on glycosylase activity of recombinant PAMAG. a Assay reaction was carried out under standard conditions except buffer used was 50 mM citrate-sodium citrate pH 3-5, phosphate-citrate pH 6-7 and Tris-Cl pH 7-9. b Effects of NaCl on glycosylase activity of recombinant PAMAG. Assay reaction was carried out under standard conditions but with 0-500 mM NaCl. c Effects of divalent cation on PfMAG activity. The 27-mer double-stranded DNA of $\varepsilon A-T$ was used as a substrate, and negative control contained no enzyme (- ve) 
Recombinant PfMAG functioned over a wide range of $\mathrm{pH}$ compared to human and Saccharomyces pombe orthologues that show an extremely narrow range of optimal pH (7.5-7.6) [50,51]. However, PfMAG demonstrated optimal activity in salt concentrations comparable to other MAG orthologues, e.g., $100 \mathrm{mM} \mathrm{NaCl}$ and $\mathrm{KCl}$ for human and $S$. pombe enzyme, respectively [50, 51], but higher concentrations (250-500 mM) inhibited activity in a dose dependent manner for all three enzymes. The roles of high-salt concentration in inhibiting glycolytic activity are variously attributed to high ionic strength, conformational changes affecting stability and/or solubility and binding of anions to catalytic site [52, 53].

Similar to other DNA glycosylases, PfMAG did not require $\mathrm{Mg}^{2+}$ or any other cofactor for damage recognition and/or excision in the assay reaction [54]. PfMAG was not affected by $\mathrm{MgCl}_{2}$ even up to $3 \mathrm{mM}$, which was different from a previous study where $\mathrm{MgCl}_{2}$ is able to stimulate and inhibit enzyme activity in a biphasic manner, the latter effect attributed to interference with substrate binding [55]. On the other hand, $\mathrm{Fe}^{2+}$ and $\mathrm{Zn}^{2+}$ were inhibitory at micromolar concentrations (Fig. 6c), with previous observation that human $N$-methylpurine-DNA glycosylase contains an amino acid residue at the active site with a potential to bind $\mathrm{Zn}^{2+}$, thereby interfering with the catalytic process [56].

\section{Conclusion}

Highest levels of PfMAG activity and its gene expression were demonstrated in schizont compared to ring and trophozoite stages. Recombinant PfMAG preferentially acted on double- rather than single-strand DNA, and had a molecular mass twice that of the human enzyme, a broad $\mathrm{pH}$ range of activity, optimal activity at $100 \mathrm{mM} \mathrm{NaCl}$, but higher concentrations were inhibitory, and no requirement for $\mathrm{Mg}^{2+}$ cofactor but $\mathrm{Fe}^{2+}$ and $\mathrm{Zn}^{2+}$ were inhibitory in micromolar range. Exploiting characteristics different from those of the human enzyme should provide insights into identifying compounds specifically targeting PfMAG, which could be developed into a potential novel anti-malarial.

\section{Supplementary information}

Supplementary information accompanies this paper at https://doi. org/10.1186/s12936-020-03355-w.

Additional file 1: Figure S1. Comparison of nucleotide sequence of MAG of Plasmodium falciparum K1 with 3D7 strain. Figure S2. Comparison of deduced amino acid sequence of MAG of Plasmodium falciparum K1 with 3 D7 strain. Figure S3. Amino acid sequence alignment of DNA-3-methyladenine glycosylase and active site region.
Abbreviations

6-FAM: 6-Carboxyfluorescein; Asn: Asparagine; Glu: Glutamic acid; His: Histidine; kDa: Kilodalton; Met: Methionine; Try: Tyrosine; WHO: World Health Organization.

\section{Acknowledgements}

The authors thank Ms. Kanthinit Thima, Department of Protozoology, Faculty of Tropical Medicine, Mahidol University for assistance in parasite culture.

\section{Authors' contributions}

NP conceived and performed experiments, data analysis, and prepared the manuscript. PL and JV participated in malaria culture, enzyme purification and western blotting. PR prepared the manuscript and artwork. PA participated in designing experiments and editing the manuscript. PCP participated in study design, data analysis, discussion, and prepared the manuscript. All authors read and approved the final manuscript.

\section{Funding}

The study was supported by Mahidol University (MU. 2558-2559) and the German Academic Exchange Service (DAAD) (for NP).

\section{Availability of data}

Data supporting results in the article are available from the corresponding author upon request.

Ethics approval and consent to participate

Not applicable.

Consent for publication

Not applicable.

Competing interests

The authors declare that they have no competing interests.

\section{Author details}

${ }^{1}$ Department of Protozoology, Faculty of Tropical Medicine, Mahidol University, Bangkok, Thailand. ${ }^{2}$ Department of Zoology, Faculty of Science, Kasetsart University, Bangkok, Thailand. ${ }^{3}$ Department of Helminthology, Faculty

of Tropical Medicine, Mahidol University, Bangkok, Thailand.

Received: 21 May 2020 Accepted: 28 July 2020

Published online: 06 August 2020

\section{References}

1. Sachs J, Malaney P. The economic and social burden of malaria. Nature. 2002:415:680-5.

2. WHO. World Malaria Report 2019. Geneva: World Health Organization; 2019. https://www.who.int/malaria/publications/world-malaria-repor t-2019/en/. Accessed 4 Dec 2019.

3. Noedl H, Se Y, Schaecher K, Smith BL, Socheat D, Fukuda MM, et al. Evidence of artemisinin-resistant malaria in western Cambodia. N Engl J Med. 2008;359:2619-20.

4. Dondorp AM, Nosten F, Yi P, Das D, Phyo AP, Tarning J, et al. Artemisinin resistance in Plasmodium falciparum malaria. N Engl J Med. 2009;361:455-67.

5. The RTS,S clinical trials partnership. A phase 3 trial of RTS, S/AS01 malaria vaccine in African infants. N Engl J Med. 2012;367:2284-95.

6. Suksangpleng T, Leartsakulpanich U, Moonsom S, Siribal S, Boonyuen U, Wright GE, et al. Molecular characterization of Plasmodium falciparum uracil-DNA glycosylase and its potential as a new anti-malarial drug target. Malar J. 2014;13:149.

7. Vasuvat J, Montree A, Moonsom S, Leartsakulpanich U, Petmitr S, Focher F, et al. Biochemical and functional characterization of Plasmodium falciparum DNA polymerase $\delta$. Malar J. 2016;15:116.

8. Limudomporn P, Moonsom S, Leartsakulpanich U, Suntornthiticharoen P, Petmitr S, Weinfeld M, et al. Characterization of Plasmodium falciparum ATP-dependent DNA helicase RuvB3. Malar J. 2016;15:526.

9. Haltiwanger BM, Matsumoto Y, Nicolas E, Dianov GL, Bohr VA, Taraschi TF. DNA base excision repair in human malaria parasites is predominantly by a long-patch pathway. Biochemistry. 2000;39:763-72. 
10. Lau AY, Schärer OD, Samson L, Verdine GL, Ellenberger T. Crystal structure of a human alkylbase-DNA repair enzyme complexed to DNA: mechanisms for nucleotide flipping and base excision. Cell. 1998;95:249-58.

11. Dosanjh MK, Chenna A, Kim E, Fraenkel-Conrat H, Samson L, Singer B. All four known cyclic adducts formed in DNA by the vinyl chloride metabolite chloroacetaldehyde are released by a human DNA glycosylase. Proc Natl Acad Sci USA. 1994:91:1024-8.

12. Saparbaev M, Kleibl K, Laval J. Escherichia coli, Saccharomyces cerevisiae, rat and human 3-methyladenine DNA glycosylases repair 1, N6-ethenoadenine when present in DNA. Nucleic Acids Res. 1995;23:3750-5.

13. Santerre A, Britt AB. Cloning of a 3-methyladenine-DNA glycosylase from Arabidopsis thaliana. Proc Natl Acad Sci USA. 1994;91:2240-4.

14. Wyatt MD, Allan JM, Lau AY, Ellenberger TE, Samson LD. 3-methyladenine DNA glycosylases: structure, function, and biological importance. Bioassays. 1999;21:668-76.

15. Engelward BP, Dreslin A, Christensen J, Huszar D, Kurahara C, Samson L. Repair-deficient 3-methyladenine DNA glycosylase homozygous mutant mouse cells have increased sensitivity to alkylation-induced chromosome damage and cell killing. EMBO J. 1996;15:945-52.

16. Paik J, Duncan T, Lindahl T, Sedgwick B. Sensitization of human carcinoma cells to alkylating agents by small interfering RNA suppression of 3-alkyladenine-DNA glycosylase. Cancer Res. 2005;65:10472-7.

17. Racine JF, Zhu Y, Mamet-Bratley MD. Mechanism of toxicity of 3-methyladenine for bacteriophage T7. Mutat Res. 1993;294:285-98.

18. Tolentino JH, Burke TJ, Mukhopadhyay S, McGregor WG, Basu AK. Inhibition of DNA replication fork progression and mutagenic potential of 1 , $\mathrm{N}^{6}$-ethenoadenine and 8-oxoguanine in human cell extracts. Nucleic Acids Res. 2008;36:1300-8.

19. Boiteux S, Laval J. Imidazole open ring 7-methylguanine: an inhibitor of DNA synthesis. Biochem Biophys Res Commun. 1983;110:552-8.

20. Pollack Y, Katzen AL, Spira DT, Golenser J. The genome of Plasmodium falciparum. I: DNA base composition. Nucleic Acids Res. 1982;10:539-46.

21. Pollack Y, Kogan N, Golenser J. Plasmodium falciparum: evidence for a DNAmethylation pattern. Exp Parasitol. 1991;72:339-44.

22. Choi SW, Keyes MK, Horrocks P. LC/ESI-MS demonstrates the absence of 5-methyl-2'-deoxycytosine in Plasmodium falciparum genomic DNA. Mol Biochem Parasitol. 2006;150:350-2.

23. Hammam E, Ananda G, Sinha A, Scheidig-Benatar C, Bohec M, Preiser PR, et al. Discovery of a new predominant cytosine DNA modification that is linked to gene expression in malaria parasites. Nucleic Acids Res. 2020;48:184-99.

24. Ponts N, Fu L, Harris EY, Zhang J, Chung DW, Cervantes MC, et al. Genome-wide mapping of DNA methylation in the human malaria parasite Plasmodium falciparum. Cell Host Microbe. 2013;14:696-706.

25. Yanow SK, Purcell LA, Lee M, Spithill TW. Genomics-based drug design targets the AT-rich malaria parasite: implications for antiparasite chemotherapy. Pharmacogenomics. 2007;8:1267-72.

26. Thaithong S, Beale GH, Chutmongkonkul M. Susceptibility of Plasmodium falciparum to five drugs: an in vitro study of isolates mainly from Thailand. Trans R Soc Trop Med Hyg. 1983;77:228-31.

27. Trager W, Jensen JB. Human malaria parasites in continuous culture. Science. 1976;193:673-5.

28. Lambros C, Vanderberg JP. Synchronization of Plasmodium falciparum erythrocytic stages in culture. J Parasitol. 1979;65:418-20.

29. Chavalitshewinkoon P, Wilairat P. A simple technique for large scale in vitro culture of Plasmodium falciparum. Southeast Asian J Trop Med Public Health. 1991;22:544-7.

30. Baker J, Gatton ML, Peters J, Ho MF, McCarthy JS, Cheng Q. Transcription and expression of Plasmodium falciparum histidine-rich proteins in different stages and strains: implications for rapid diagnostic tests. PLOS ONE. 2011:6:e22593.

31. Livak KJ, Schmittgen TD. Analysis of relative gene expression data using realtime quantitative PCR and the 2- $\triangle \triangle C$ t method. Methods. 2001;25:402-8.

32. Zhang Y. I-TASSER server for protein $3 D$ structure prediction. BMC Bioinform. 2008:9:40.

33. Roy A, Kucukural A, Zhang Y. I-TASSER: a unified platform for automated protein structure and function prediction. Nat Protoc. 2010;5:725-38.

34. Yang J, Yan R, Roy A, Xu D, Poisson J, Zhang Y. The I-TASSER Suite: protein structure and function prediction. Nat Methods. 2015;12:7-8.

35. Rydberg B, Lindahl T. Nonenzymatic methylation of DNA by the intracellular methyl group donor S-adenosyl-L-methionine is a potentially mutagenic reaction. EMBO J. 1982;1:211-6.
36. Asaeda A, Ide H, Asagoshi K, Matsuyama S, Tano K, Murakami A, et al. Substrate specificity of human methylpurine DNA N-glycosylase. Biochemistry. 2000;39:1959-65.

37. Singer B, Antoccia A, Basu AK, Dosanjh MK, Fraenkel-Conrat H, Gallagher PE, et al. Both purified human 1, N6-ethenoadenine-binding protein and purified human 3-methyladenine-DNA glycosylase act on 1, N6-ethenoadenine and 3-methyladenine. Proc Natl Acad Sci USA. 1992;89:9386-90.

38. Lee CYI, Delaney JC, Kartalou M, Lingaraju GM, Maor-Shoshani A, Essigmann JM, et al. Recognition and processing of a new repertoire of DNA substrates by human 3-methyladenine DNA glycosylase (AAG). Biochemistry. 2009;48:1850-61.

39. Alseth I, Osman F, Korvald H, Tsaneva I, Whitby MC, Seeberg E, et al. Biochemical characterization and DNA repair pathway interactions of Mag1-mediated base excision repair in Schizosaccharomyces pombe. Nucleic Acids Res. 2005;33:1123-31.

40. Lau AY, Wyatt MD, Glassner BJ, Samson LD, Ellenberger T. Molecular basis for discriminating between normal and damaged bases by the human alkyladenine glycosylase, AAG. Proc Natl Acad Sci USA. 2000;97:13573-8.

41. Foth BJ, Zhang N, Mok S, Preiser PR, Bozdech Z. Quantitative protein expression profiling reveals extensive post-transcriptional regulation and post-translational modifications in schizont-stage malaria parasites. Genome Biol. 2008;9:R177.

42. Le Roch KG, Johnson JR, Florens L, Zhou Y, Santrosyan A, Grainger M, et al. Global analysis of transcript and protein levels across the Plasmodium falciparum life cycle. Genome Res. 2004;14:2308-18.

43. Schwanhausser B, Busse D, Li N, Dittmar G, Schuchhardt J, Wolf J, et al. Global quantification of mammalian gene expression control. Nature. 2011:473:337-42.

44. Shi L, Kent R, Bence N, Britt AB. Developmental expression of a DNA repair gene in Arabidopsis. Mutat Res. 1997;384:145-56.

45. Song S, Xing G, Yuan L, Wang J, Wang S, Yin Y, et al. N-methylpurine DNA glycosylase inhibits p53 mediated cell cycle arrest and coordinates with $p 53$ to determine sensitivity to alkylating agents. Cell Res. 2012;22:1285-303.

46. Samson L, Derfler B, Boosalis M, Call K. Genetics Cloning and characterization of a 3-methyladenine DNA glycosylase CDNA from human cells whose gene maps to chromosome 16. Proc Natl Acad Sci USA. 1991;88:9127-31.

47. Bjelland S, Seeberg E. Different efficiencies of the Tag and AlkA DNA glycosylases from Escherichia coli in the removal of 3-methyladenine from single-stranded DNA. FEBS Lett. 1996:397:127-9.

48. Eftedal I, Guddal PH, Slupphaug G, Volden G, Krokan HE. Consensus sequences for good and poor removal of uracil from double stranded DNA by uracil-DNA glycosylase. Nucleic Acids Res. 1993;21:2095-101.

49. Haushalter KA, Todd Stukenberg MW, Kirschner MW, Verdine GL. Identification of a new uracilDNA glycosylase family by expression cloning using synthetic inhibitors. Curr Biol. 1999;9:174-85.

50. O'Connor Timothy R. Purification and characterization of human 3-methyladenine-DNA glycosylase. Nucleic Acids Res. 1993;21:5561-9.

51. Memisoglu A, Samson L. Cloning and characterization of a cDNA encoding a-methyladenine DNA glycosylase from the fission yeast Schizosaccharomyces pombe. Gene. 1996;177:229-35.

52. Warren JC, Cheatum SG. Effect of neutral salts on enzyme activity and structure. Biochemistry. 1966;5:1702-7.

53. Park C, Raines RT. Quantitative analysis of the effect of salt concentration on enzymatic catalysis. J Am Chem Soc. 2001;123:11472-9.

54. Izumi T, Wiederhold LR, Roy G, Roy R, Jaiswal A, Bhakat KK, et al. Mammalian DNA base excision repair proteins: their interactions and role in repair of oxidative DNA damage. Toxicology. 2003;15:43-65.

55. Adhikari S, Toretsky JA, Yuan L, Roy R. Magnesium, essential for base excision repair enzymes, inhibits substrate binding of $\mathrm{N}$-methylpurine-DNA glycosylase. J Biol Chem. 2006;281:29525-32.

56. Wang $\mathrm{P}$, Guliaev AB, Hang B. Metal inhibition of human N-methylpurine-DNA glycosylase activity in base excision repair. Toxicol Lett. 2006;166:237-47.

\section{Publisher's Note}

Springer Nature remains neutral with regard to jurisdictional claims in published maps and institutional affiliations. 